\title{
Simple and Efficient Rout for Synthesis of Spinel Nanopigments
}

\author{
Leila Torkian, ${ }^{1}$ Maryam Daghighi, ${ }^{2}$ and Zahra Boorboor ${ }^{2}$ \\ ${ }^{1}$ Applied Chemistry Department, Islamic Azad University, South Tehran Branch, 209, North Iranshahr Street, Tehran 11365/4435, Iran \\ ${ }^{2}$ Chemistry Department, Islamic Azad University, Central Tehran Branch, Tehran 11365/4435, Iran
}

Correspondence should be addressed to Leila Torkian; ltorkian@azad.ac.ir

Received 6 May 2013; Accepted 29 July 2013

Academic Editor: Laura Crociani

Copyright (C) 2013 Leila Torkian et al. This is an open access article distributed under the Creative Commons Attribution License, which permits unrestricted use, distribution, and reproduction in any medium, provided the original work is properly cited.

\begin{abstract}
Nano-sized $\mathrm{Co}_{x} \mathrm{Mg}_{1-x} \mathrm{Al}_{2} \mathrm{O}_{4}(x=0,0.1,0.2,0.4,0.6,0.8$, and 1) inorganic pigments were synthesized via combustion method using $\beta$-alanine, as a single and novel fuel, at $800^{\circ} \mathrm{C}$ in open furnace. The obtained powders were characterized by means of $\mathrm{X}$ ray diffraction (XRD), energy dispersive X-ray (EDX) elemental analysis, diffuse reflectance spectrum (DRS), CIE $L^{*} a^{*} b^{*}$ color measurements, and scanning electron microscope (SEM). XRD patterns show that all calcined powders have single phase cubic spinel structure. EDX analysis revealed the composition of desired spinels. The diffuse reflectance spectra of the $\mathrm{Co}_{x} \mathrm{Mg}_{1-x} \mathrm{Al}_{2} \mathrm{O}_{4}$ $(x>0)$ pigments confirmed the presence of tetrahedrally coordinated $\mathrm{Co}^{2+}$ ions in the spinel lattice. The colorimetric data pointed out the formation of blue pigments (for $x>0$ ), corresponding to highly negative values of $b^{*}$, and the bluest color was produced for $x=0.8$ and 1 . SEM images showed nanoparticles with less than $30 \mathrm{~nm}$ crystallite size and flakes-like appearance of all synthesized powders.
\end{abstract}

\section{Introduction}

Inorganic blue pigments are widely used in industry to bring color to plastics, paints, fibers, papers, rubbers, glass, cement, glazes, ceramics, and porcelain enamels [1]. The traditional source of blue color in inorganic pigments depended on cobalt ion [2]. As cobalt is scarce and expensive, spinel type $\mathrm{Co}_{x} \mathrm{Mg}_{1-x} \mathrm{Al}_{2} \mathrm{O}_{4}(0<x<1)$ allows for a reduction of the production costs and environmental problems [3]. Moreover owing to the high mechanical resistance, high thermal and chemical stability, and low temperature sinterability of spineltype oxide materials, $\mathrm{Co}_{x} \mathrm{Mg}_{1-x} \mathrm{Al}_{2} \mathrm{O}_{4}$ feels a need for qualified nanoinorganic blue pigment [4].

In recent years, a variety of techniques, such as coprecipitation [5], solid state reaction [6], hydrothermal synthesis [7], and sol-gel [8] and combustion syntheses [9], have been developed and successfully used for the preparation of pure spinel powders. The synthesis route is very important for determining the final properties of inorganic pigment such as color, particle size, and chemical and thermal stability. The liquid combustion method has the advantage of preparing crystalline powders with nanosize and high purity at low temperatures [10]. In this work nanocrystalline $\mathrm{Co}_{x} \mathrm{Mg}_{1-x} \mathrm{Al}_{2} \mathrm{O}_{4}$ spinel pigment has been synthesized via low-temperature combustion route employing $\beta$-alanine as a novel environmentally benign fuel [11] and characterized by applying different techniques.

\section{Materials and Methods}

2.1. Powder Synthesis. Merck (Germany) analytical reagents were used as raw materials: cobalt nitrate hexahydrate (Co $\left.\left(\mathrm{NO}_{3}\right)_{2} \cdot 6 \mathrm{H}_{2} \mathrm{O}\right)$, magnesium nitrate hexahydrate $\left(\mathrm{Mg}\left(\mathrm{NO}_{3}\right)_{2}\right.$. $\left.6 \mathrm{H}_{2} \mathrm{O}\right)$, aluminium nitrate nonahydrate $\left(\mathrm{Al}\left(\mathrm{NO}_{3}\right)_{3} \cdot 9 \mathrm{H}_{2} \mathrm{O}\right)$, and $\beta$-alanine $\left(\mathrm{C}_{3} \mathrm{H}_{7} \mathrm{NO}_{2}\right)$. An aqueous solution containing $\mathrm{Mg}(\mathrm{II}), \mathrm{Al}(\mathrm{III})$, and $\mathrm{Co}(\mathrm{II})$ metal ion salts and fuel was heated at $60^{\circ} \mathrm{C}$ under continuous stirring. After $1 \mathrm{~h}$, the temperature was raised to $80^{\circ} \mathrm{C}$, and the mixture was stirred for several hours until a pink-reddish gel was formed. The used ratio $\mathrm{M}(\mathrm{II}) / \mathrm{Al}(\mathrm{III})\{\mathrm{M}(\mathrm{II})=\mathrm{Mg}$ and $\mathrm{Co}\}$ is 0.5 , and $M_{\text {total }} / \beta$-alanine $\left\{M_{\text {total }}=\mathrm{M}(\mathrm{II})\right.$ and $\left.\mathrm{Al}(\mathrm{III})\right\}$ was 4 according 
to the following equation:

$$
\begin{array}{r}
(1-x) \mathrm{Mg}\left(\mathrm{NO}_{3}\right)_{2} \cdot 6 \mathrm{H}_{2} \mathrm{O}+x \mathrm{Co}\left(\mathrm{NO}_{3}\right)_{2} \cdot 6 \mathrm{H}_{2} \mathrm{O} \\
+2 \mathrm{Al}\left(\mathrm{NO}_{3}\right)_{3} \cdot 9 \mathrm{H}_{2} \mathrm{O}+4 \mathrm{C}_{3} \mathrm{H}_{7} \mathrm{NO}_{2}+5 \mathrm{O}_{2} \\
\longrightarrow \mathrm{Co}_{x} \mathrm{Mg}_{1-x} \mathrm{Al}_{2} \mathrm{O}_{4}+12 \mathrm{CO}_{2}+38 \mathrm{H}_{2} \mathrm{O}+6 \mathrm{~N}_{2}
\end{array}
$$

The blue mixed oxide has been obtained after a heat treatment of the gel precursors at $\mathrm{T}=800^{\circ} \mathrm{C}$ for $1 \mathrm{~h}$, with a heating rate of $30 \mathrm{~K} / \mathrm{min}$ in an open furnace in air atmosphere.

2.2. Characterization Methods. X-ray diffraction patterns were recorded using a $D_{4}$-BRUKER diffractometer (Germany) by $\mathrm{Cu} \mathrm{K} \alpha$ radiation at $20 \mathrm{KV}$ and $30 \mathrm{~mA}$. A Philips XL $\Phi-30$ scanning electron microscope (SEM Tech Solutions, North Billerica, MA, USA) was used to observe the morphology of nanoparticles. The infrared spectra of the powders were taken in a Thermo Scientific Nicolate iS 10 FT-IR (USA) equipment, in the $4000-400 \mathrm{~cm}^{-1}$ region. The elemental analysis of the powders was performed by electron dispersive $\mathrm{X}$-ray analysis (EDAX) (FEI Inspect $\mathrm{S}$ Eindhoven). Diffuse reflectance spectra and CIE $L^{*} a^{*} b^{*}$ chromatic coordinates were determined using a Varian UV-VIS spectrophotometer (Cary 300 Bio, Mulgrave, VIC, Australia) under D65 illuminant and $10^{\circ}$ standard observer angle.

\section{Result and Discussion}

Figure 1 depicts the XRD patterns of the samples from the $\mathrm{Co}_{x} \mathrm{Mg}_{1-x} \mathrm{Al}_{2} \mathrm{O}_{4}$ system heat treated at $800^{\circ} \mathrm{C}$. At this temperature for all the values of $x$ studied, the characteristic peaks of the spinel structure were noticed, according to the JCPDS files 21-1152 and 10-0458, for $\mathrm{MgAl}_{2} \mathrm{O}_{4}$ and $\mathrm{CoAl}_{2} \mathrm{O}_{4}$, respectively. The patterns did not show the presence of secondary phases. The development of the spinel phase at a relatively low temperature indicates one advantage of this synthesis route, as compared with other methods [12].

Table 1 shows the crystallite sizes of the calcined pigments $\mathrm{Co}_{x} \mathrm{Mg}_{1-x} \mathrm{Al}_{2} \mathrm{O}_{4}(x=0,0.1,0.2,0.4,0.6,0.8$, and 1) based on the XRD patterns using the Williamson-Hall method: $B \cdot \operatorname{Cos}(\theta)=\mathrm{K} \lambda / D+\eta \cdot \operatorname{Sin}(\theta)$, where $D$ is the crystallite size, $B$ is the full width at half-maximum intensity (FWHM) of the diffraction line, $\theta$ is the Bragg angle, $K$ is a dimensionless shape factor with a value close to unity and ranges from 0.8 to $1.39, \lambda$ is the X-ray wavelength $(0.15418 \mathrm{~nm})$, and $\eta$ is related to strain. Based on the XRD data for $x=0.8$, when we plotted $B \cdot \operatorname{Cos}(\theta)$ versus $\operatorname{Sin}(\theta)$ we got a straight line with intercept $0.00907(Y=0.0004 X+0.00907)$; therefore the crystallite size $(D)$ was estimated to $17 \mathrm{~nm}$. Same measurements led to calculate the crystallite sizes of other samples with different $x$ values by applying the Williamson-Hall method (Table 1). All samples had crystallite sizes bellow $30 \mathrm{~nm}$ and the smallest size was obtained for $x=0.2(6.8 \mathrm{~nm})$. It seems that low level of cobalt content decreases the crystallite size of nanopigments. Experimental results evidenced that Co enrichment has different effects on crystallite sizes of $\mathrm{Co}^{2+}$ doped spinels synthesized via combustion method in the

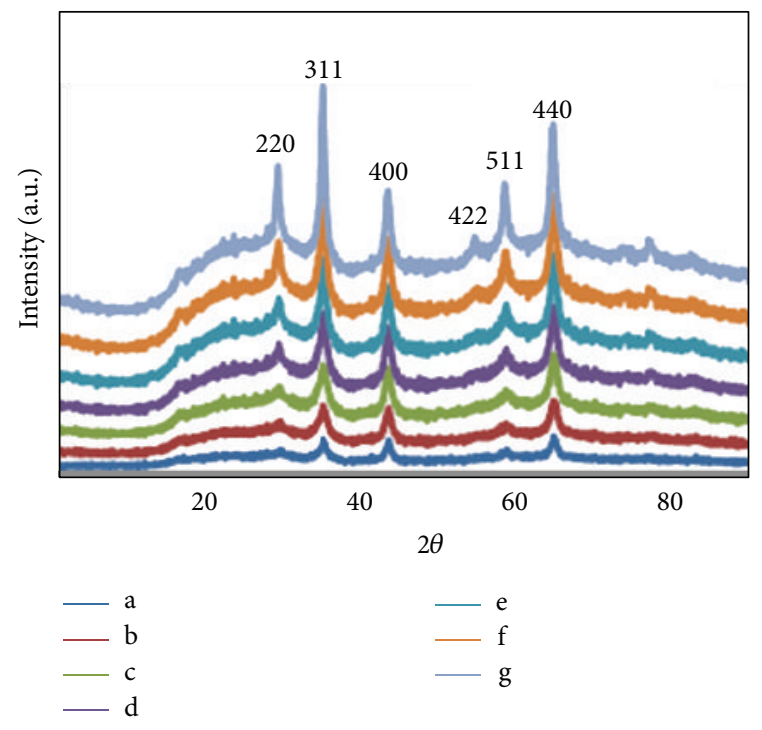

FIGURE 1: Powder X-ray diffraction patterns of $\mathrm{Co}_{x} \mathrm{Mg}_{1-x} \mathrm{Al}_{2} \mathrm{O}_{4}\{x=$ $0(\mathrm{a}), 0.1(\mathrm{~b}), 0.2(\mathrm{c}), 0.4(\mathrm{~d}), 0.6(\mathrm{e}), 0.8(\mathrm{f})$, and $1(\mathrm{~g})\}$ calcinated for $1 \mathrm{~h}$ at $800^{\circ} \mathrm{C}$.

presence of various fuels [13]. According to Ionas et al., $\beta$-alanine is a suitable fuel for $\mathrm{Mg}\left(\mathrm{NO}_{3}\right)_{2}$, while urea is preferred for $\mathrm{Co}\left(\mathrm{NO}_{3}\right)_{2}$. Employing mixtures of urea and $\beta$-alanine to prepare $\mathrm{Co}_{x} \mathrm{Mg}_{1-x} \mathrm{Al}_{2} \mathrm{O}_{4}$, resulted in smaller crystallite sizes in high cobalt contents [11]. It seems that applying $\beta$-alanine as a sole fuel in our work resulted in higher combustion temperatures and larger crystallite sizes in Co-enrichment samples.

The chromatic coordinates $\left(L^{*}, a^{*}\right.$ and $\left.b^{*}\right)$ are also displayed in Table 1. It can be seen that the lightness, $L^{*}$, decreases with the increase of the Co content, pointing out the formation of darker pigments. The coordinate $a^{*}$ is kept negative for all the samples, indicating a slight green condition. In terms of the $b^{*}$ coordinate, negative values lead to a blue color for all the samples, except for $x=0$ which excludes of $\mathrm{Co}^{2+}$ ions, with the tendency of showing the highest blue intensity for the high level of Co content. These results confirm the visual observations (Figure 2) which indicate that the appearance of intense blue color in pigment powders occurs for $x=1$ and 0.8 ; however as low $\mathrm{Co}^{+2}$ content is preferred, $x=0.1$ is recommended. There are different reports about the relation between the cobalt content and observed blue colors of other spinel type pigments. According to de Souza et al. higher Co enrichment leads to darker blue pigments, but the most negative values of $b^{*}$ are observed in medium cobalt content samples in the $\mathrm{Co}_{x} \mathrm{Zn}_{1-x} \mathrm{Al}_{2} \mathrm{O}_{4}$ system [13].

The $x$-dependence of lattice constant which is calculated by applying the XRD data is depicted in Table 2 . Accompanying the decreasing tendency shown in the theoretical values for the lattice parameters of $\mathrm{CoAl}_{2} \mathrm{O}_{4}(8.106 \AA)$ and $\mathrm{MgAl}_{2} \mathrm{O}_{4}$ $(8.086 \AA)$, the experimental values of lattice parameters gradually decrease upon the Co substitution by $\mathrm{Mg}$, from $8.101 \AA$ to $8.087 \AA$. Such reduction in the lattice constants in agreement with the values from JCPDS files 10-0458 and 21-1152, for $\mathrm{CoAl}_{2} \mathrm{O}_{4}$ and $\mathrm{MgAl}_{2} \mathrm{O}_{4}$, respectively, confirmed 


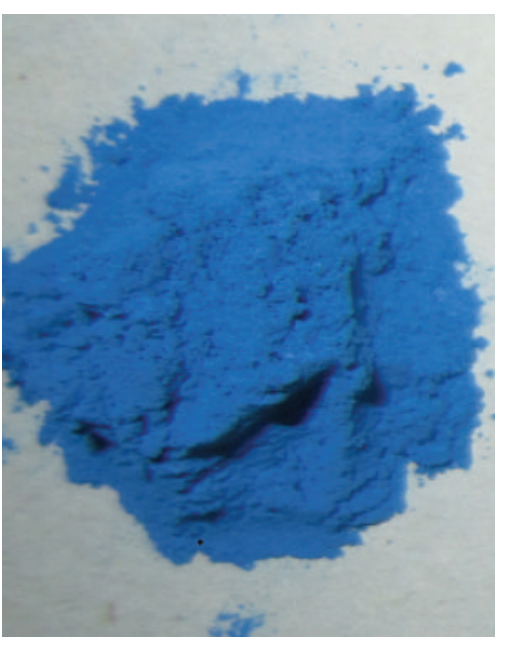

(a)

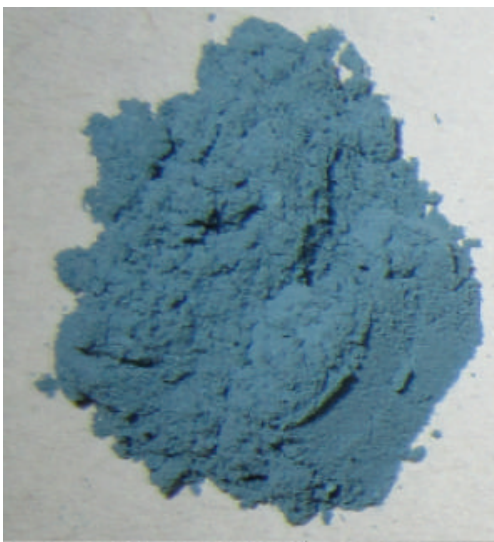

(d)

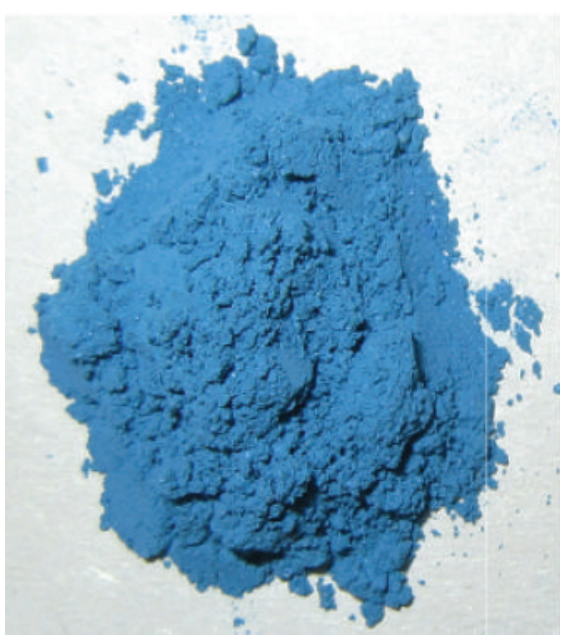

(b)

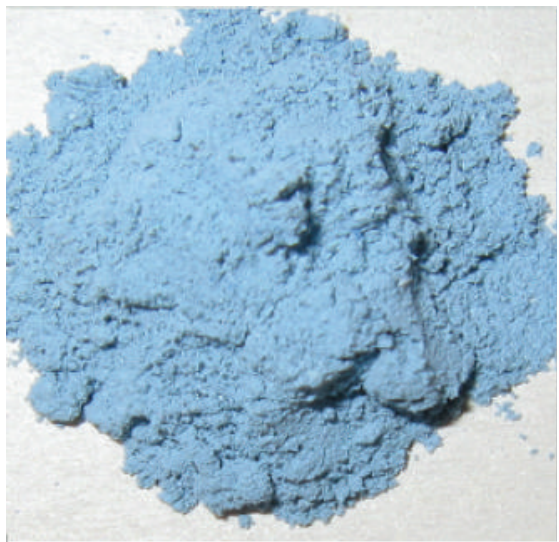

(e)

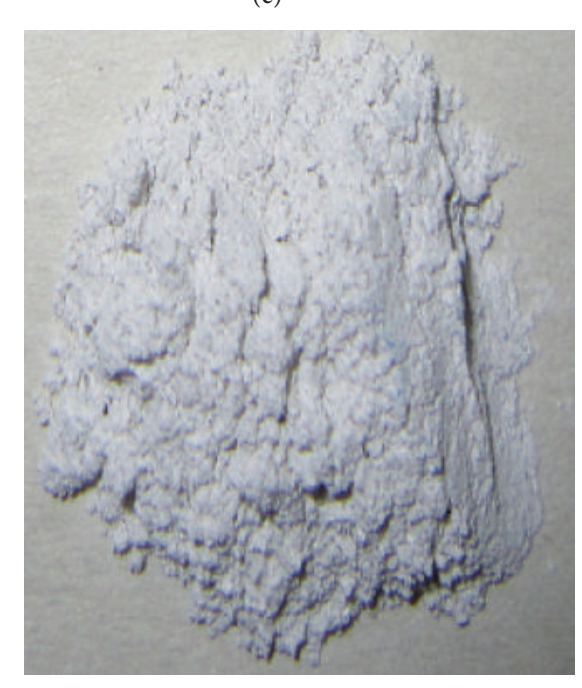

(g)

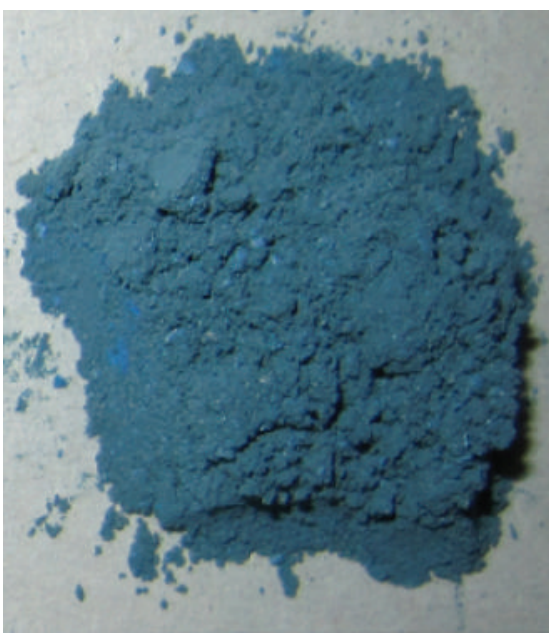

(c)

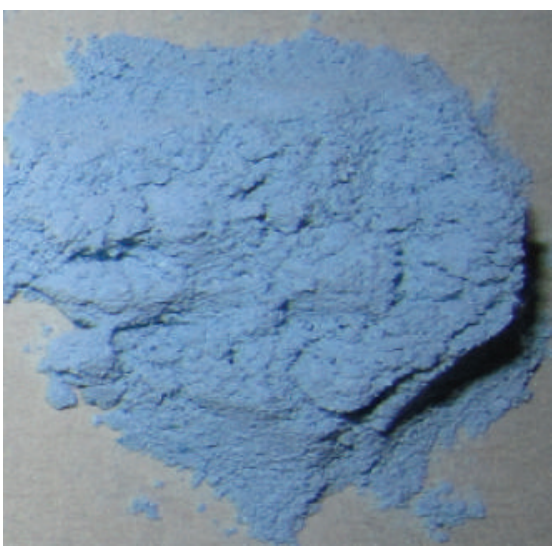

(f)

FIGURE 2: Various colors for $\mathrm{Co}_{x} \mathrm{Mg}_{1-x} \mathrm{Al}_{2} \mathrm{O}_{4}\{x=1(\mathrm{a}), 0.8(\mathrm{~b}), 0.6(\mathrm{c}), 0.4(\mathrm{~d}), 0.2(\mathrm{e}), 0.1(\mathrm{f})$, and $0(\mathrm{~g})\}$.

the successful occupation of magnesium ion instead of cobalt ion in tetrahedral sites. Similar results have been reported by de Souza et al. [13].

Figure 3 shows the results of the electron dispersive $\mathrm{X}$-ray analysis (EDAX) for $\mathrm{Co}_{0.8} \mathrm{Mg}_{0.2} \mathrm{Al}_{2} \mathrm{O}_{4}$ sample.
From the elemental analysis in combination with the results obtained from EDAX, the stoichiometry of the precursor heated at $800^{\circ} \mathrm{C}$ for $1 \mathrm{~h}$ was found to be $7.87 \%$ (atom percent) of Co, $2.12 \%$ of $\mathrm{Mg}, 23.44 \%$ of $\mathrm{Al}$, and $65.97 \%$ of $\mathrm{O}$. This observation, corroborated with the XRD analysis result on 
TABLE 1: Crystallite size and colorimetric analysis of the calcined samples.

\begin{tabular}{|c|c|c|c|c|c|}
\hline Sample & Crystallite size (nm) & $L^{*}$ & $a^{*}$ & $b^{*}$ & $\Delta E$ \\
\hline $\mathrm{CoAl}_{2} \mathrm{O}_{4}$ & 27 & 41.5 & -10.6 & -30.815 & 52.765 \\
\hline $\mathrm{Co}_{0.8} \mathrm{Mg}_{0.2} \mathrm{Al}_{2} \mathrm{O}_{4}$ & 17 & 43.2 & -14.5 & -18.125 & 49.040 \\
\hline $\mathrm{Co}_{0.6} \mathrm{Mg}_{0.4} \mathrm{Al}_{2} \mathrm{O}_{4}$ & 13 & 45.7 & -12.2 & -6.171 & 47.72 \\
\hline $\mathrm{Co}_{0.4} \mathrm{Mg}_{0.6} \mathrm{Al}_{2} \mathrm{O}_{4}$ & 18 & 50.4 & -12.0 & -6.213 & 52.23 \\
\hline $\mathrm{Co}_{0.2} \mathrm{Mg}_{0.8} \mathrm{Al}_{2} \mathrm{O}_{4}$ & 7 & 63.7 & -10.6 & -10.612 & 65.52 \\
\hline $\mathrm{Co}_{0.1} \mathrm{Mg}_{0.9} \mathrm{Al}_{2} \mathrm{O}_{4}$ & 9 & 71.4 & -8.1 & -12.57 & 73 \\
\hline $\mathrm{MgAl}_{2} \mathrm{O}_{4}$ & 8 & 81.8 & -0.31 & 2.501 & 81.93 \\
\hline
\end{tabular}

TABLE 2: Lattice parameter of $\mathrm{Co}_{x} \mathrm{Mg}_{1-x} \mathrm{Al}_{2} \mathrm{O}_{4}(x=0,0.1,0.2,0.4$, $0.6,0.8$, and 1$)$, heat treated at $800^{\circ} \mathrm{C}$.

\begin{tabular}{lc}
\hline Sample & Lattice parameter/A \\
\hline $\mathrm{CoAl}_{2} \mathrm{O}_{4}$ & 8.101 \\
$\mathrm{Co}_{0.8} \mathrm{Mg}_{0.2} \mathrm{Al}_{2} \mathrm{O}_{4}$ & 8.097 \\
$\mathrm{Co}_{0.6} \mathrm{Mg}_{0.4} \mathrm{Al}_{2} \mathrm{O}_{4}$ & 8.096 \\
$\mathrm{Co}_{0.4} \mathrm{Mg}_{0.6} \mathrm{Al}_{2} \mathrm{O}_{4}$ & 8.094 \\
$\mathrm{Co}_{0.2} \mathrm{Mg}_{0.8} \mathrm{Al}_{2} \mathrm{O}_{4}$ & 8.090 \\
$\mathrm{Co}_{0.1} \mathrm{Mg}_{0.9} \mathrm{Al}_{2} \mathrm{O}_{4}$ & 8.089 \\
$\mathrm{MgAl}_{2} \mathrm{O}_{4}$ & 8.087 \\
\hline
\end{tabular}

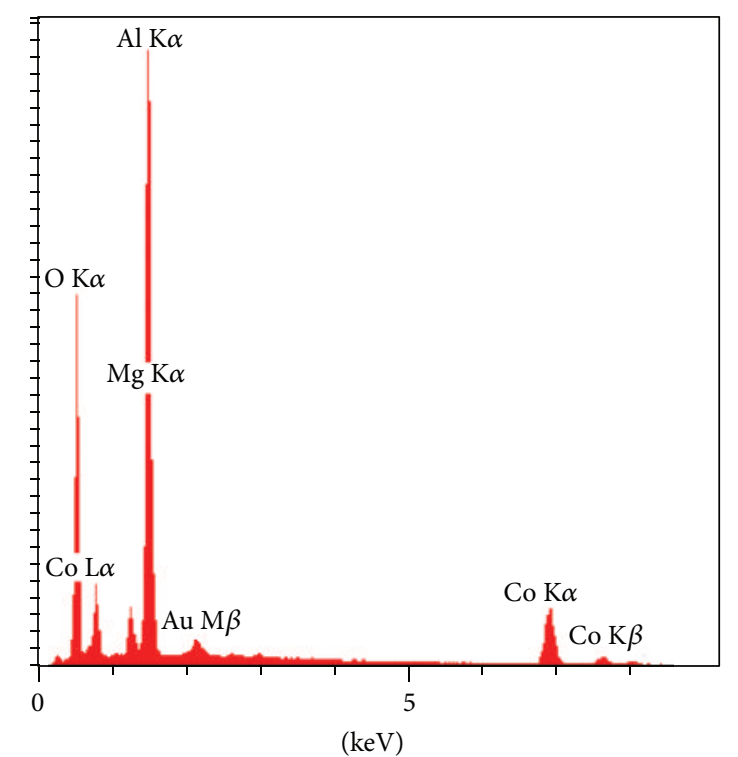
Mg: $2.12 \%$ at.
Al: $23.44 \%$ at.
Co: $7.87 \%$ at.
O: $65.97 \%$ at.

Figure 3: X-ray emission pattern of $\mathrm{Co}_{0.8} \mathrm{Mg}_{0.2} \mathrm{Al}_{2} \mathrm{O}_{4}$ powder and its elemental composition.

the calcined powder, indicates the formation of the designed spinel with desired chemical composition. Same results have been obtained for other values of $x$, too.

Diffuse reflectance spectroscopy (DRS) (Figure 4) indicates the appearance of three bands centered at approximately 550,580 , and $620 \mathrm{~nm}$, which are attributed to the spinallowed ${ }^{4} \mathrm{~A}_{2}(\mathrm{~F}) \rightarrow{ }^{4} \mathrm{~T}_{1}(\mathrm{P})$ transition of the $\mathrm{Co}^{2+}$ ions in

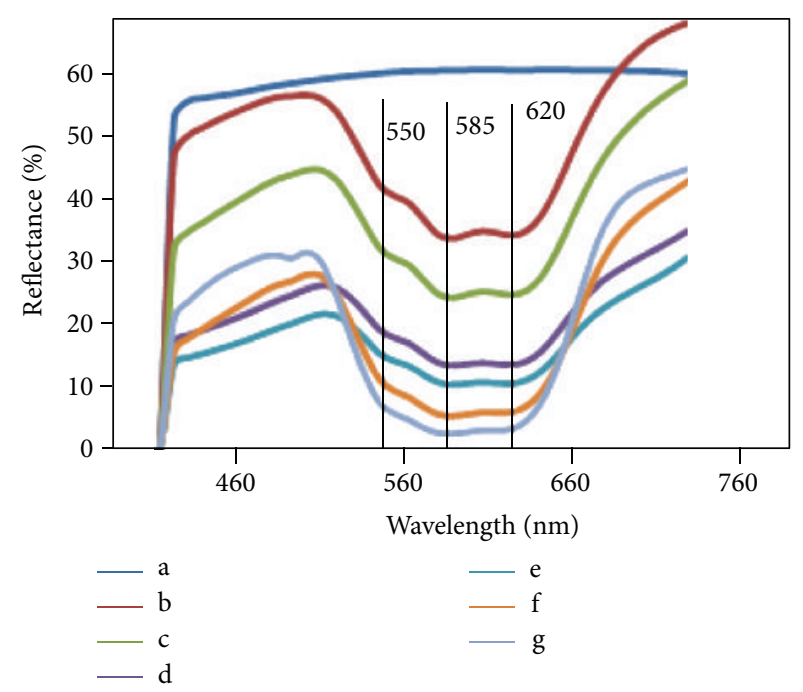

FIgURE 4: Diffuse reflectance spectra for the calcined powders of $\mathrm{Co}_{x} \mathrm{Mg}_{1-x} \mathrm{Al}_{2} \mathrm{O}_{4}\{x=0(\mathrm{a}), 0.1(\mathrm{~b}), 0.2(\mathrm{c}), 0.4(\mathrm{~d}), 0.6(\mathrm{e}), 0.8(\mathrm{f})$, and $1(\mathrm{~g})\}$.

tetrahedral sites. Same results were reported in the spectroscopic characterization of $\mathrm{CoAl}_{2} \mathrm{O}_{4}$ coatings by Stangar et al. [14] and Zayat and Levy [15].

SEM characterization of the powders (Figure 5) revealed a homogeneous microstructure and a similar morphology (flakes-like appearance) of all powders, similar to the reports of Ionas et al. for the preparation of $\mathrm{Mg}_{1-x} \mathrm{Co}_{x} \mathrm{Al}_{2} \mathrm{O}_{4}(x=$ $0.1-0.3$ ) blue pigments by applying mixtures of fuels [11]. The decrease of the agglomeration degree for lower cobalt content $(x=0.2$ and 0.1$)$ is obvious.

In previous reports, pure and crystalline $\mathrm{Mg}_{1-x} \mathrm{Co}_{x} \mathrm{Al}_{2} \mathrm{O}_{4}$ powders were obtained only after annealing the as-prepared amorphous powders at high temperatures [16, 17]. Few reports on this topic show that the preparation of same ceramic pigments involves annealing at $1400^{\circ} \mathrm{C}$ for $3 \mathrm{~h}$ [4]. Even applying new methods such as sonochemical synthesis requires heating treatment at $1000^{\circ} \mathrm{C}$ at least for 2 hours for the formation of pure cobalt aluminate spinel phase [18]. Generally, increasing temperature treatment increases the crystallite sizes of powders [19-22]. So preparation of single phase spinel nanoparticles at lower temperatures is the advantage of our liquid combustion method and makes it technically simple and cost effective. In our previous work 


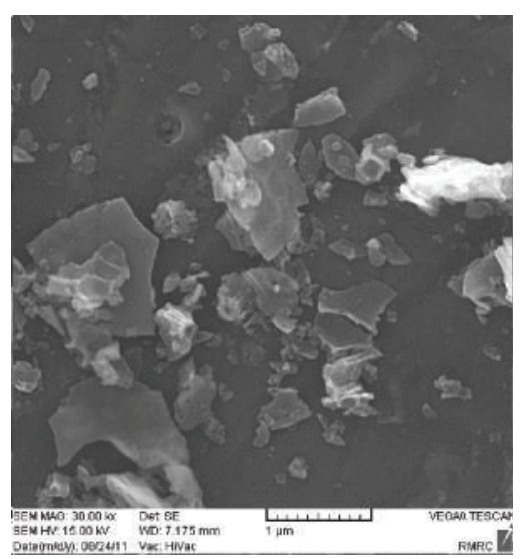

(a)

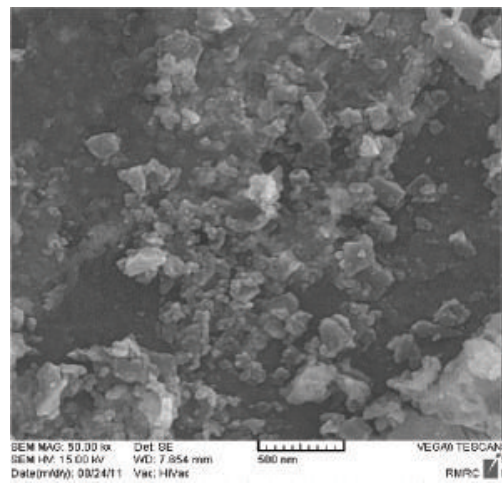

(d)

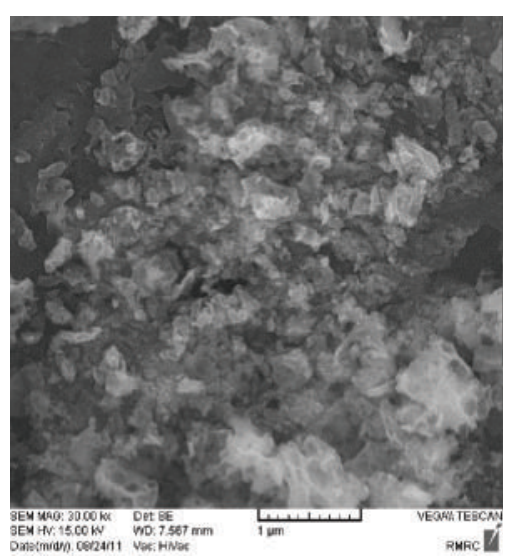

(b)

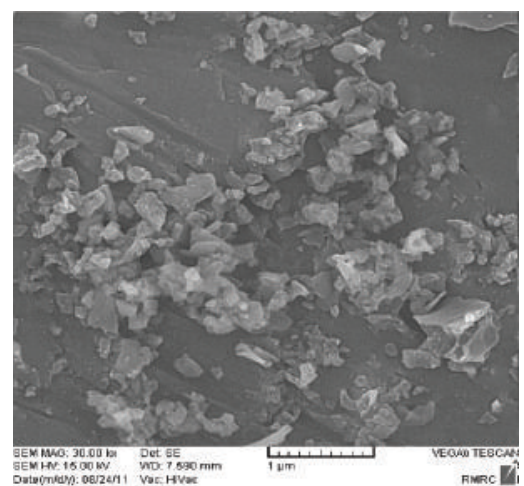

(e)

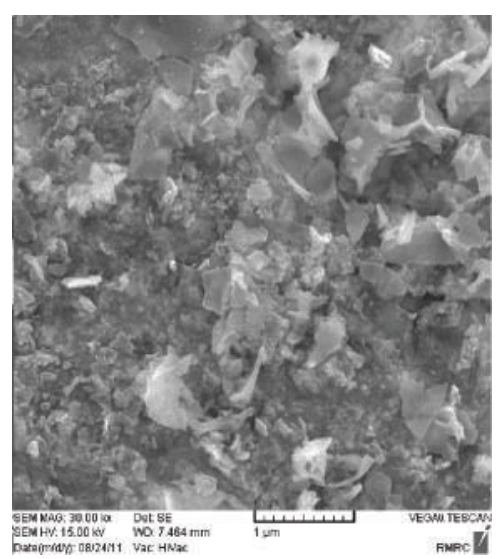

(c)

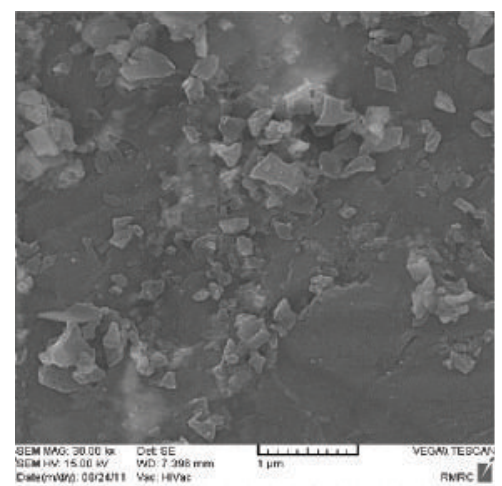

(f)

FIGURE 5: SEM images of the calcined powders of $\mathrm{Co}_{x} \mathrm{Mg}_{1-x} \mathrm{Al}_{2} \mathrm{O}_{4}\{x=1(\mathrm{a}), 0.8(\mathrm{~b}), 0.6(\mathrm{c}), 0.4(\mathrm{~d}), 0.2(\mathrm{e})$, and $0.1(\mathrm{f})\}$. The scale is in 1 micrometer.

applying starch instead of $\beta$-alanine resulted in the formation of black and grayish blue nanopigments for most values of $x$ in the preparation of $\mathrm{Co}_{x} \mathrm{Mg}_{1-x} \mathrm{Al}_{2} \mathrm{O}_{4}$ [23]. It seems that applying $\beta$-alanine improves the presence of tetrahedrally coordinated $\mathrm{Co}^{2+}$ ions in the spinel lattice.

\section{Conclusions}

Blue inorganic nanopigments $\mathrm{Co}_{x} \mathrm{Mg}_{1-x} \mathrm{Al}_{2} \mathrm{O}_{4}(x=0.1,0.2$, $0.4,0.6,0.8$, and 1 ) have been prepared, via a combustion process using stoichiometric amounts of corresponding metal nitrates and $\beta$-alanine as an environmentally benign fuel. Relatively low synthesis temperature was employed, once the single and pure spinel phases were identified for all nanopigments by XRD and EDAX analyses. SEM micrographs revealed a homogenous flakes-like microstructure with a tendency to reduce the agglomeration degree for lower cobalt contents $(x=0.2$ and 0.1$)$. Appearance of bands around $550-630 \mathrm{~nm}$ in diffuse reflectance spectra confirmed the presence of $\mathrm{Co}^{2+}$ ions in tetrahedral sites of the spinel structure. CIE $L^{*} a^{*} b^{*}$ chromatic coordinates indicated that the blue color was obtained for all nanopigments. Although the cobalt enrichment increases the intensity of blue color, low $\mathrm{Co}^{2+}$ content $(x=0.1)$ is recommended in order to reduce the cost and environmental problems. These facts reveal that $\beta$-alanine can be employed lonely as a novel and environmentally benign fuel to prepare $\mathrm{Co}_{x} \mathrm{Mg}_{1-x} \mathrm{Al}_{2} \mathrm{O}_{4}$ $(x=0.1,0.2,0.4,0.6,0.8$, and 1$)$ spinels in an efficient, low temperature combustion method. These spinel nanopigments with intense blue color are thermally and chemically stable and offer potential industrial applications.

\section{Acknowledgments}

This work was financially supported by the south Tehran branch and central Tehran branch of the Islamic Azad University.

\section{References}

[1] W. Li, J. Li, and J. Guo, "Synthesis and characterization of nanocrystalline $\mathrm{CoAl}_{2} \mathrm{O}_{4}$ spinel powder by low temperature combustion " Journal of the European Ceramic Society, vol. 23, pp. 2289-2295, 2003.

[2] I. S. Ahmed, S. A. Shama, M. M. Moustafa, H. A. Dessouki, and A. A. Ali, "Synthesis and spectral characterization of $\mathrm{Co}_{x} \mathrm{Mg}_{1-x} \mathrm{Al}_{2} \mathrm{O}_{4}$ as new nano-coloring agent of ceramic pigment," Spectrochimica Acta A, vol. 74, no. 3, pp. 665-672, 2009.

[3] A. E. Giannakas, A. K. Ladavos, G. S. Armatas, and P. J. Pomonis, "Surface properties, textural features and catalytic 
performance for $\mathrm{NO}+\mathrm{CO}$ abatement of spinels $\mathrm{MAl}_{2} \mathrm{O}_{4}$ ( $\mathrm{M}=\mathrm{Mg}$, Co and $\mathrm{Zn}$ ) developed by reverse and bicontinuous microemulsion method," Applied Surface Science, vol. 253, no. 16, pp. 6969-6979, 2007.

[4] M. Llusar, A. Forés, J. A. Badenes, J. Calbo, M. A. Tena, and G. Monrós, "Colour analysis of some cobalt-based blue pigments," Journal of the European Ceramic Society, vol. 21, no. 8, pp. 11211130, 2001.

[5] S. Britto, A. V. Radha, N. Ravishankar, and P. V. Kamath, "Solution decomposition of the layered double hydroxide (LDH) of Zn with Al," Solid State Sciences, vol. 9, no. 3-4, pp. 279-286, 2007.

[6] T. Suzuki, H. Nagai, and M. Nohara, "Melting of antiferromagnetic ordering in spinel oxide $\mathrm{CoAl}_{2} \mathrm{O}_{4}$," Journal of Physics, vol. 19, Article ID 145265, 2007.

[7] Z. Chen, E. Shi, and Y. Zheng, "Hydrothermal synthesis of nanosized $\mathrm{CoAl}_{2} \mathrm{O}_{4}$ on $\mathrm{ZnAl}_{2} \mathrm{O}_{4}$ seed crystallites," Journal of the American Ceramic Society, vol. 86, no. 6, pp. 1058-1060, 2003.

[8] C. Luan, D. Yuan, and X. Duan, "Synthesis and characterization of $\mathrm{Co}^{2+}: \mathrm{MgAl}_{2} \mathrm{O}_{4}$ nanocrystal," Journal of Sol-Gel Science and Technology, vol. 38, pp. 245-249, 2006.

[9] A. T. Aruna and A. S. Mukasyan, "Combustion synthesis and nanomaterials," Current Opinion in Solid State \& Materials Science, vol. 12, pp. 44-50, 2008.

[10] R. Ianos and R. Laza, "Combustion synthesis, characterization and sintering behavior of magnesium aluminate $\left(\mathrm{MgAl}_{2} \mathrm{O}_{4}\right)$ powders ," Materials Chemistry and Physics, vol. 115, pp. 645648, 2009.

[11] R. Ianos, R. Laza, and P. Barvinschi, "Synthesis of $\mathrm{Mg}_{1-x} \mathrm{Co}_{x} \mathrm{Al}_{2} \mathrm{O}_{4}$ blue pigments via combustion route," Advanced Powder Technology, vol. 22, pp. 396-400, 2011.

[12] P. M. T. Cavalcante, M. Dondi, G. Guarini, M. Raimondo, and G. Baldi, "Colour performance of ceramic nano-pigments," Dyes and Pigments, vol. 80, no. 2, pp. 226-232, 2009.

[13] L. K. C. de Souza, J. R. Zamian, G. N. da Rocha Filho et al., "Blue pigments based on $\mathrm{Co}_{x} \mathrm{Zn}_{1-x} \mathrm{Al}_{2} \mathrm{O}_{4}$ spinels synthesized by the polymeric precursor method," Dyes and Pigments, vol. 81, no. 3, pp. 187-192, 2009.

[14] U. L. Stangar, B. Orel, and M. Krajnc, "Preparation and spectroscopic characterization of blue $\mathrm{CoAl}_{2} \mathrm{O}_{4}$ coatings," Journal of Sol-Gel Science and Technology, vol. 26, pp. 771-775, 2003.

[15] M. Zayat and D. Levy, "Blue $\mathrm{CoAl}_{2} \mathrm{O}_{4}$ particles prepared by the sol-gel and citrate-gel methods," Chemistry of Materials, vol. 12, no. 9, pp. 2763-2769, 2000.

[16] L. F. Koroleva, "Synthesis of spinel-based ceramic pigments from hydroxycarbonates," Glass and Ceramics, vol. 61, no. 9-10, pp. 299-302, 2004.

[17] D. Visinescu, C. Paraschiv, A. Ianculescu, B. Jurca, B. Vasile, and O. Carp, "The environmentally benign synthesis of nanosized $\mathrm{Co}_{x} \mathrm{Zn}_{1-x} \mathrm{Al}_{2} \mathrm{O}_{4}$ blue pigments," Dyes and Pigments, vol. 87, no. 2, pp. 125-131, 2010.

[18] W. Lv, Q. Qiu, F. Wang, S. Wei, B. Liu, and Z. Luo, "Sonochemical synthesis of cobalt aluminate nanoparticles under various preparation parameters," Ultrasonics Sonochemistry, vol. 17, no. 5, pp. 793-801, 2010.

[19] R. C. Singh, M. P. Singh, and O. Singh, "Influence of synthesis and calcination temperatures on particle size and ethanol sensing behaviour of chemically synthesized $\mathrm{SnO} 2$ nanostructures ," Sensors and Actuators B, vol. 143, no. 1, pp. 226-232, 2009.

[20] S. Udomporn and S. Ananta, "Effect of calcination condition on phase formation and particle size of lead titanate powders synthesized by the solid-state reaction "' Materials Letters, vol. 58, no. 7-8, pp. 1154-1159, 2004.

[21] L. Torkian, M. M. Amini, and Z. Bahrami, "Synthesis of nano crystalline $\mathrm{MgAl}_{2} \mathrm{O}_{4}$ spinel powder by microwave assisted combustion," Journal of Inorganic Materials, vol. 26, no. 5, pp. 550-554, 2011.

[22] A. Saberi, F. Golestani-Fard, and M. Willert-Porada, "A novel approach to synthesis of nanosize $\mathrm{MgAl}_{2} \mathrm{O}_{4}$ spinel powder through sol-gel citrate technique and subsequent heat treatment ", Ceramics International, vol. 35, no. 3, pp. 933-937, 2009.

[23] L. Torkian, E. Radmanesh, and M. Daghighi, "Microwave assisted combustion synthesis of nano crystalline $\mathrm{CoAl}_{2} \mathrm{O}_{4}$ spinel powder," in Proceedings of the 11th International Conference on Atomically Controlled Surfaces, Interfaces and Nanostructure, St. Peteresburg, Russia, 2011. 

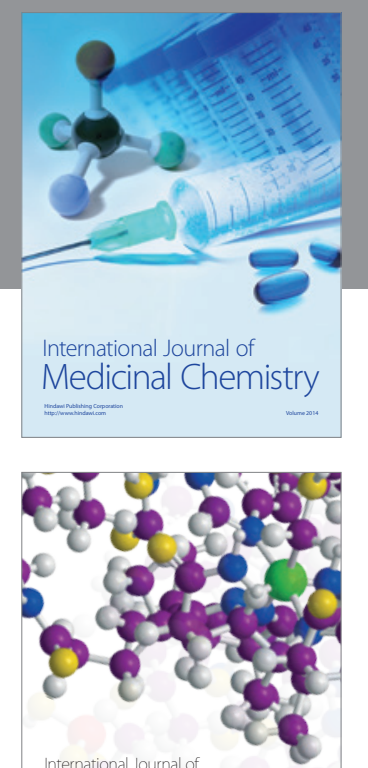

\section{Carbohydrate} Chemistry

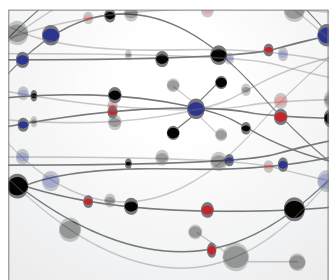

The Scientific World Journal
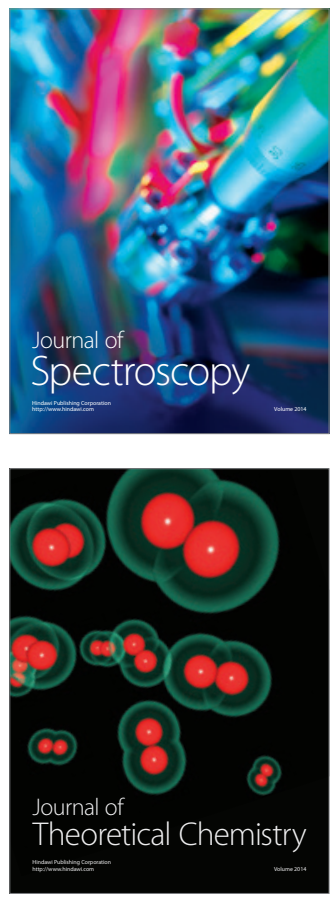
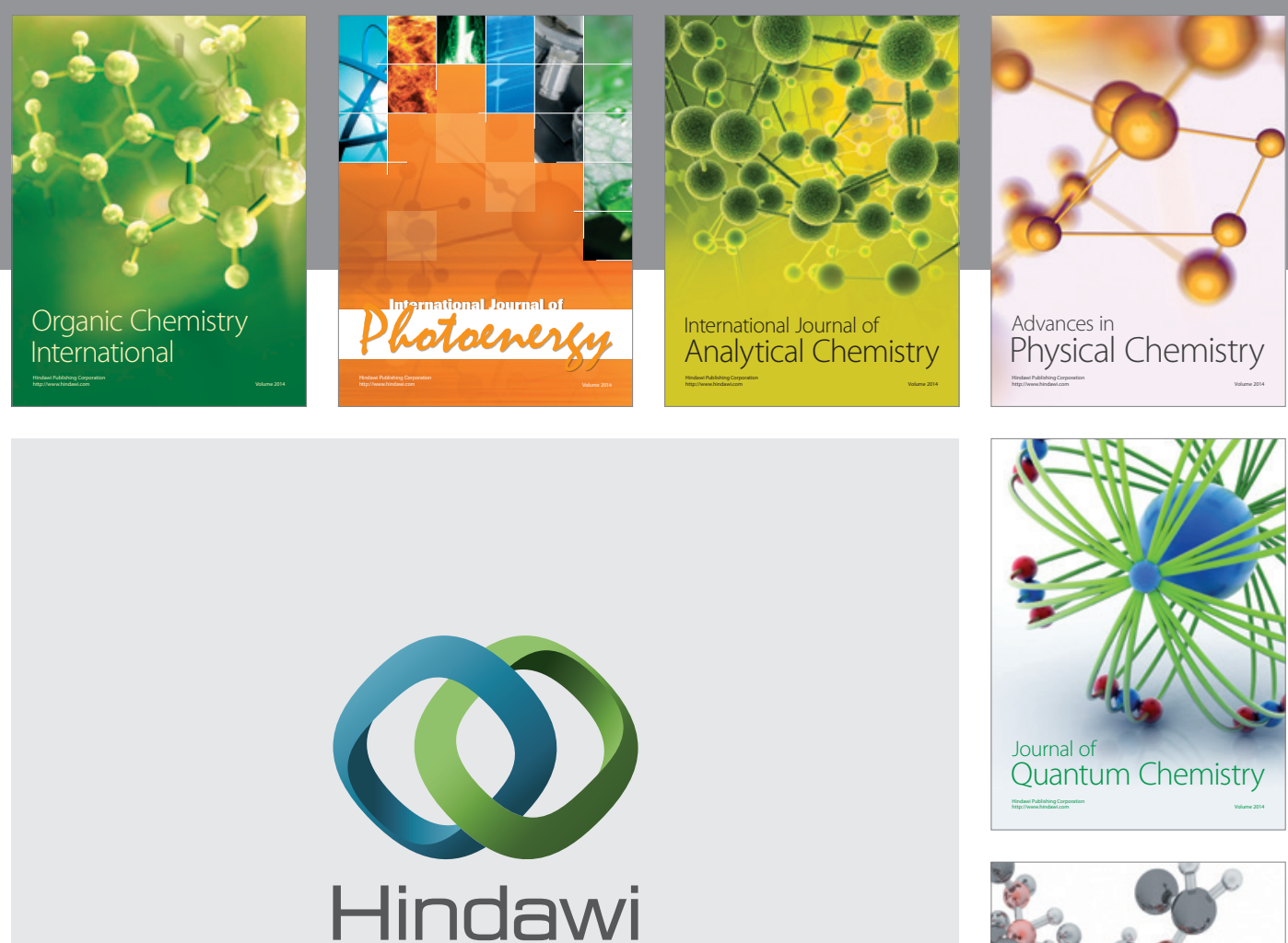

Submit your manuscripts at

http://www.hindawi.com

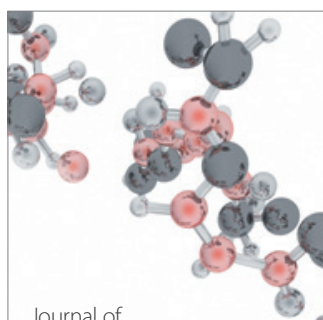

Analytical Methods

in Chemistry

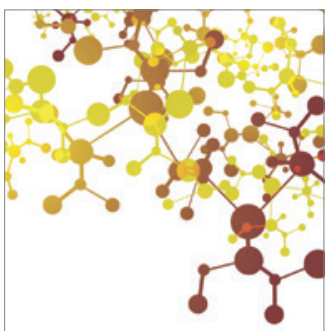

Journal of

Applied Chemistry

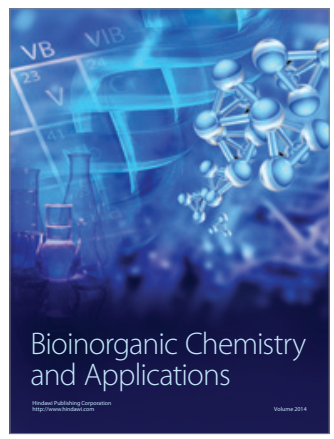

Inorganic Chemistry
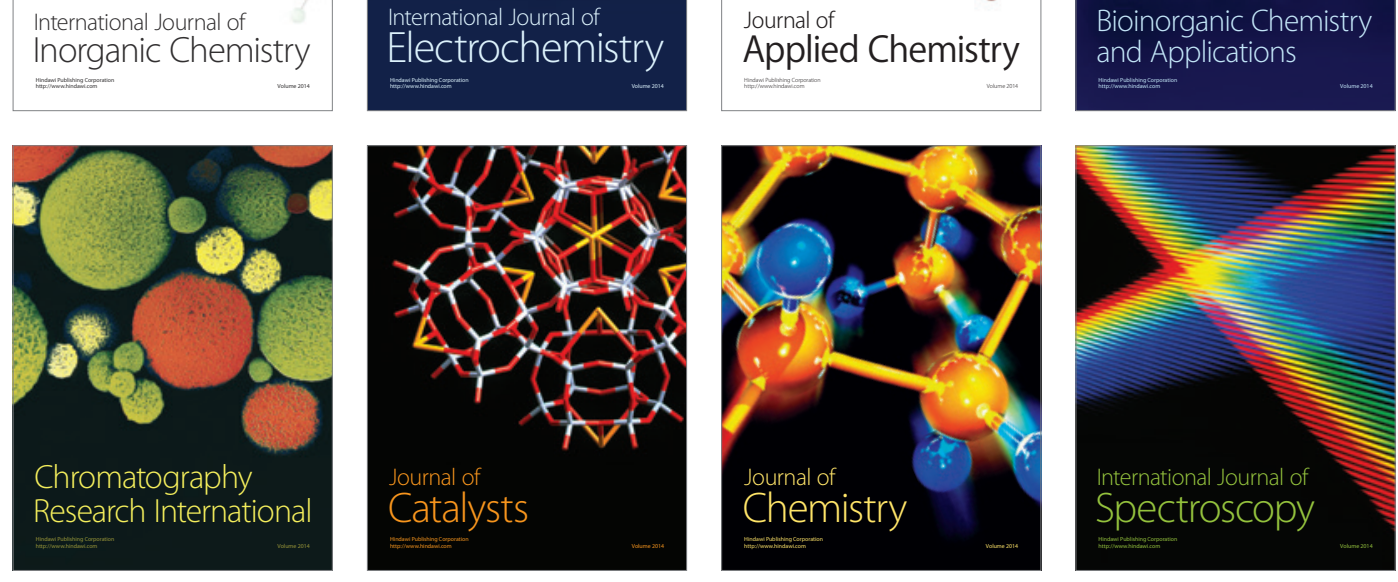